Alina Molisak

\title{
Żyd patrzy na chłopa... Wiejskie przestrzenie i chłopscy bohaterowie. Kilka przykładów z literatury jidysz
}

\section{THE JEW IS LOOKING AT THE PEASANT... RURAL SPACES AND PEASANT HEROES: SOME EXAMPLES FROM YIDDISH LITERATURE}

\begin{abstract}
The article is an analysis of several texts from Jewish literature. The main purpose is to see how the characters of villagers were construed and how the rural space functioned in texts created by Yiddish writers. Rural space is the sphere of professional and sociocultural contacts within which heroes are placed and by which their fate is influenced. Jewish-peasant relations are the most interesting aspects of the narratives.
\end{abstract}

Keywords: Jews, peasants, countryside, social and cultural relations.

Słowa kluczowe: Żydzi, chłopi, wieś, relacje społeczno-kulturowe.

Refleksja nad tekstami kultury łączącymi tematykę żydowską i chłopską dotychczas najczęściej obejmowała analizy, w których uwaga badaczy koncentrowała się na rekonstrukcji figur żydowskich czy polskich bohaterów albo na opisaniu rozmaitych środków użytych do tworzenia narracji (wraz z przedstawieniem wykorzystanych schematów i stereotypów). Najważniejsze spośród przeprowadzonych badań zajmowały się literaturą polską (Magdalena Opalski, Mieczysław Inglot i inni) oraz literatura powstałą w języku jidysz lub hebrajskim (Dan Miron, Chone Shmeruk, Israel Bartal, David G. Roskies). Omawiano przy tym piśmiennictwo, które prezentowało bardzo różne typy bohaterów bądź relacje między polskimi 
i żydowskimi środowiskami ${ }^{1}$. Rozpatrywano sfery kontaktów, jakimi były przestrzenie miast, a przede wszystkim fenomen sztetla (Dan Miron, Yohanan Petrovsky-Shtern), zwracano uwagę na wspólne związki czy funkcjonowanie wyobrażeń ujawniających schematy wzajemnego postrzegania ${ }^{2}$. Zdecydowana większość wskazanych prac koncentrowała się na relacjach żydowsko-chłopskich oraz postaciach chłopskich bohaterów umiejscowionych w przestrzeni najbardziej klasycznej - czyli żydowskiego miasteczka, sztetla. Jeśli przedstawiano analizy dotyczące przestrzeni wiejskich oraz tego, jak opisywani są funkcjonujący w nich bohaterowie, najczęściej wybierano postaci nie tyle chłopów, ile dziedziców czy właścicieli majątków, które dzierżawili Żydzi (np. Israel Bartal, Dan Miron)³. Israel Bartal wprawdzie zwracał uwagę na traktowanie przez I. L. Pereca chłopskich postaci ujmowanych w odbiegający od schematów czy karykatur sposób: „Portretując chłopów, Perec pozostaje dość blisko rolniczego, wiejskiego życia, a fragmenty, które opisują współczesne spotkania pomiędzy polskimi chłopami a Żydami, odnoszą się do ówczesnych realiów ekonomicznych"4. W tymże artykule badacz zwraca jednak uwagę na ewolucję widoczną w prozie Pereca i obecne w niej od początku XX w. koncentrowanie uwagi „na totalnej konfrontacji pomiędzy Żydem a nie-Żydem, którą symbolizuje relacja pomiędzy »porecem« a dzierżawcą. $[. .$.$] odejście od okazywania$ współczucia dla polskiego chłopa"5.

Wydaje się zatem interesującym zagadnieniem zbadanie, jak konstruowane były postaci mieszkańców wsi i jak funkcjonowała wiejska przestrzeń w tekstach stworzonych przez pisarzy żydowskich, w omawianym

${ }^{1}$ Zob. Magdalena Opalski, The Jewish Tavern-Keeper and His Tavern in Nineteenth-Century Polish Literature, Jerusalem 1986; Mieczysław Inglot, Postać Żyda w literaturze polskiej lat 1822-1864, Wrocław 1999. Interesującym zbiorem jest także tom Kwestia żydowska w XIX wieku. Spory o tożsamość Polaków, red. Grażyna Borkowska, Magdalena Rudkowska, Warszawa 2004.

2 Zob. Israel Bartal, Non-Jews and Gentile Society in East European Hebrew and Yiddish Literature, 1856-1914, „Polin” 4 (1989), s. 53-69; Heidi Hein-Kircher, Inge Blank, I. L. Peretz' Blick auf das shtetl: Die Reportage über seine Provinzreise in historischer Perspektive, „Aschkenas” 11 (2001), nr 2, s. 497-513; Steven T. Katz (red.), The Shtetl: New Evaluations, New York 2007; Dan Miron, The Image of the Shtetl and Other Studies of Modern Jewish Literary Imagination, Syracuse 2001; Gennady Estraikh, Mikhail Krutikov (red.), The Shtetl: Image and Reality, Oxford 2000; Yohanan Petrovsky-Shtern, Sztetl. Rozkwit i upadek żydowskich miasteczek na Kresach Wschodnich, tłum. Joanna Gilewicz, Kraków 2014.

${ }^{3}$ Israel Bartal, „Porec” $i$ arendarz. Portret Polaków w literaturze żydowskiej, thum. Emilia Padoł, [w:] Polskie tematy i konteksty literatury żydowskiej, red. Eugenia Prokop-Janiec, Marek Tuszewicki, Kraków 2014, s. 63- 76; Miron, The Image of the Shtetl...

4 Bartal, „Porec” $i$ arendarz..., s. 74.

5 Tamże, s. 75. 
wypadku tych, którzy pisali w jidysz. Inne jeszcze zbiory piśmiennictwa, gdzie te wątki również występują, to literatura polsko-żydowska oraz teksty powstałe w języku hebrajskim. Temat obszernie zakreślony, rozumiany jako warianty obecności chłopskich bohaterów i przedstawienia wiejskich przestrzeni we wskazanym powyżej dziedzictwie literackim, wymagałby stworzenia zespołu badawczego, bardzo obszernych studiów filologicznych i kulturoznawczych, dokładnej lektury literatury żydowskiej powstałej w wielu językach. Prezentowany artykuł, w którym zajmuję się tylko kilkoma utworami prozatorskimi powstałymi w jidysz, jest zatem wyłącznie zasygnalizowaniem interesującego, jak sądzę, pola badawczego.

Na terenach Europy Środkowo-Wschodniej istotnym czynnikiem decydującym o wyborze miejsca osiedlania się Żydów były rozmaite podlegające nieustannym zmianom - prawa i przywileje oraz zakazy wydawane przez konkretnych władców. W zasadniczy sposób wpłynęły one na kształtowanie się struktury zawodowej, a także na możliwości tworzenia przez Żydów niewielkich gospodarstw chłopskich bądź posiadania większych majątków ziemskich. Związki mieszkańców żydowskich ze światem wsi ewoluowały i zmieniały swą formułę, zwłaszcza od połowy XIX w., zależnie od terenu zaborów (należy tu brać pod uwagę różnice między Królestwem Kongresowym a Galicją) $)^{6}$. Najpowszechniejszą formą obecności żydowskiej na wsi była jednak - jak się wydaje - dzierżawa czy arenda. $\mathrm{Z}$ raczej marginalnym, choć interesującym zjawiskiem mamy do czynienia wówczas, gdy powstają żydowskie osady wiejskie lub gdy w ręce żydowskie przechodzą niewielkie folwarki

Wszystkie te procesy przemian znalazły swoje odbicie również na łamach wielojęzycznej literatury żydowskiej ${ }^{8}$. Osobnym, bardzo obszernym zbiorem tekstów opisujących obecność żydowską w wiejskich przestrzeniach są z jednej strony reportaże lub pisane po latach wspomnienia relacjonujące

${ }^{6}$ Nie omawiam tu licznych prac historyków dotyczących tej tematyki. Interesuje mnie przede wszystkim obecność wiejskich przestrzeni i postaci chłopów w tekstach literackich. O obecności Żydów na wsiach, osadnictwie i uprawie roli pisali m.in.: Majer Bałaban, Kiedy i skąd przybyli Żydzi do Polski, Warszawa 1931; Studia z dziejów Żydów w Polsce. Materiały edukacyjne dla szkót średnich i wyższych, t. 1, red. Zofia Borzymińska, Warszawa 1995; Wojciech Roszkowski, Gospodarcza rola większej prywatnej własności ziemskiej w Polsce 19181939, Warszawa 1986; Żydzi w Polsce. Dzieje i kultura. Leksykon, red. Jerzy Tomaszewski, Andrzej Żbikowski, Warszawa 2001; Antony Polonsky, Dzieje Żydów w Polsce i Rosji, tłum. Mateusz Wilk, Warszawa 2014.

7 Zob. Wirtualny Sztetl, Muzeum Historii Żydów Polskich Polin, http://www.sztetl.org. pl/pl [dostęp: 4 października 2017].

${ }^{8}$ Pamiętając o polisystemie językowym literatury żydowskiej powstałej na ziemiach polskich, wybieram dla potrzeb tego artykułu kilka prozatorskich utworów powstałych w jidysz. 
funkcjonowanie żydowskich dworów, z drugiej zaś źródła etnograficzne, badania nad folklorem czy wreszcie prace naukowe z I połowy XX w. poświęcone osadnikom żydowskim oraz wiejskim koloniom zakładanym przez Żydów9.

Chciałabym zwrócić uwagę jedynie na kilka wybranych narracji literackich dotyczących przebywania Żydów na wsi, relacji chłopsko-żydowskich i postrzegania przez żydowskich twórców społeczności chłopskiej. Wiejskie przestrzenie występują na łamach przywołanych tekstów w co najmniej trzech wariantach:

1. jako teren działalności gospodarczej - odbywa się tam handel obwoźny, działa wzięta w arendę karczma bądź dzierżawione są łąki, lasy, młyny;

2. jako obszar, gdzie mieszkają Żydzi (raczej nieczęsto na stałe);

3. jako miejsce życia i działania bohatera, który może zostać uznany za figure ,żydowskiego dziedzica” - byłaby to literacka wersja zapisu zjawisk historycznych dość rzadkich, ale znaczących.

Dla analizy tych zapisów warto przywołać - znane i stosowane już w rozważaniach nad literaturą - kategorie takie jak: ,przejęty z krytyki postkolonialnej model »trzeciej przestrzeni « Homiego Bhabhy, koncepcję contact zone (»strefy kontaktu «) Mary Louise Pratt i model żydowskich nowoczesnych subkultur powstających w wyniku procesów akulturacyjnych" ${ }^{10}$. Wskazując na te perspektywy (Bhabha, Pratt) oraz wykorzystując je do badań, Eugenia Prokop-Janiec zwróciła uwagę na możliwości ich zastosowania do analiz rozmaitych tekstów kultury ${ }^{11}$. W przypadku „strefy kontaktu” chodzi nie tyle o rejestrowanie hierarchii społecznych czy podziałów w obrębie mieszkających na tym samym terytorium jednostek, ile o wspólną obecność w konkretnej przestrzeni, rodzaje interakcji, relacji ustanawianych pomiędzy tym, co swojskie, i tym, co odmienne, swoistą rekonstrukcję społecznych stratyfikacji. Jak to dookreśliła badaczka:

Strefa kontaktu to przestrzeń ambiwalencji, obszar doświadczenia przymusu, nierówności i konfliktu, ale też współdziałania i koegzystencji. Dochodzi tu z jednej strony do nawiązywania międzyosobowych relacji, z drugiej - do uruchamiania

${ }_{9}$ Pisałam o jednym z takich zjawisk w artykule Żydzi-chłopi, „Teksty Drugie” (2017), nr 6, s. 238-249.

${ }^{10}$ Eugenia Prokop-Janiec, Kategoria pogranicza we wspótczesnych studiach żydowskich, [w:] taż, Pogranicze polsko-żydowskie. Topografie i teksty, Kraków 2013, s. 30.

11 Tamże. 
przez grupę mniejszościową procesów selekcjonowania, adaptacji, przyswajania elementów kultury dominującej ${ }^{12}$.

Procesy tak opisywane odnaleźć można w literackich narracjach, gdzie mowa o lokowanych w wiejskich przestrzeniach bohaterach żydowskich dostrzegających odmienność otoczenia, choć bardzo różnie na tę odmienność reagujących.

\section{Żydowscy arendarze i dzierżawcy}

Postać mieszkającego na wsi, samotnego Żyda najczęściej chyba bywa związana z dzierżawą karczmy. W tomie Notatki komiwojażera autorstwa Szolema Alejchema znajduje się krótkie opowiadanie pt. Dziesiaty ${ }^{13}$. Jest ono rodzajem groteskowej narracji, zapisem poszukiwania tego, kto dopełni grupkę niezbędną do minjanu. Szkatułkowa struktura tekstu pozwala na przywołanie - w jednym z krótkich wtrąceń - dziejów bezdzietnego arendarza mieszkającego we dworze. Ów bohater żyje wprawdzie w zasobnym domu („Dwór był wielki, przestronny”14), ale poza nim i żoną nie ma wokół żadnych Żydów. Wiejska przestrzeń to obszar, który został scharakteryzowany jednym zdaniem: „Wprawdzie znalazłbyś tam wielu chrześcijan, lecz ani jednego Żyda - prócz arendarza"15. Gdy wreszcie po latach pojawia się w tej żydowskiej rodzinie męski potomek, na uroczystość obrzezania zasobny arendarz sprowadza z miasta ,rabina, szocheta z szamesem i jeszcze pięciu Żydów"16. W pewnej chwili zauważono jednak, że przejęty emocjami i uradowany ojciec nieuważnie policzył mężczyzn niezbędnych do odmówienia modlitwy. Trudno było temu zaradzić, gdyż wokół mieszkali sami chłopi: „Wieś duża, ale ani jednego Żyda”17. Krytyczną sytuację uratował przejeżdżający żydowski woźnica, dzięki któremu można było dopełnić minjanu. Przywołana historyjka daje narratorowi asumpt do podkreślenia parabolicznej wymowy opowieści: „Teraz widzimy,

${ }^{12}$ Eugenia Prokop-Janiec, Kulturowe i literackie kontakty polsko-żydowskie, [w:] Polacy - Żydzi. Kontakty kulturowe i literackie, red. Eugenia Prokop-Janiec, Kraków 2014, s. 17.

${ }_{13}$ Szolem Alejchem, Dziesiaty, [w:] tenże, Notatki komiwojażera, tłum. Jakub Appenszlak, Warszawa 1958.

${ }_{14}$ Tamże, s. 188.

15 Tamże.

16 Tamże.

17 Tamże, s. 189. 
jak wielki jest nasz Bóg! Cała wieś nie poradzi. A tu zjawia się jeden Żyd, furman, i już dobrze!"18.

Najczęstszym chyba, oprócz figury arendarza, żydowskim bohaterem nawiązującym bezpośrednie stosunki ze światem chłopskim jest - o czym już wspominałam - postać dzierżawcy. W opowiadaniu Pereca pt. Zamęście ojciec narratorki ,był pisarzem i za trzy ruble tygodniowo pracował w lesie u reb Zajnwełe Terkielbijma" ${ }^{19}$. Wspomniany jedynie mimochodem reb Zajnwełe Terkielbijm jest dzierżawcą pańskiego lasu. Prowadzi z miejscowym chłopstwem swoistą walkę konkurencyjną, o której opowiada bohater zatrudniony przezeń do pomocy i spisywania danych dotyczących wyrębów:

Rąbano jednocześnie w dwudziestu miejscach. Ty rozumiesz o co chodzi? Las jest dziedzica, ale chłopi mają serwituty; do nich należą konary spadające z drzew, a także drzewa rażone piorunem... No, a jeśli rąbią las, przepadają im serwituty. Muszą sobie wówczas kupować drzewo na opał i budulec. Więc chcieli, ma się rozumieć, nałożyć areszt na las, sprowadzić komisarza; namyślili się jednak zbyt późno. Gdy reb Zajnwełe zauważył, że chłopi drapią się w głowy i namyślają nad czymś, rozkazał natychmiast zatrudnić jeszcze czterdziestu drwali! Zaczęło się piekło! Rąbano, jak już powiedziałem, może w dwudziestu miejscach. A wszędzie trzeba doglądnąć... Co ty sobie myślisz? Nogi mi tam spuchły jak te konwie ${ }^{20}$.

W przywołanym cytacie bardzo precyzyjnie określony zostaje trójkąt relacji między właścicielem lasu, czyli dziedzicem, żydowskim dzierżawcą a chłopami. Dziedzic jest nieobecny w narracji, a zatem także w przestrzeni potencjalnego konfliktu interesów. Główny zaś spór rozgrywa się między reb Zajnwełem Terkielbijmem a chłopami troszczącymi się o własne zyski, czyli gwarantowane im prawem serwituty.

W opowiadaniu Icchoka Lejbusza Pereca zatytułowanym Spuszczone oczy mamy do czynienia z dramatem córek żydowskiego arendarza ${ }^{21}$. Ojciec dwóch dziewcząt, choć bywający w mieście, mieszka wraz z rodziną na wsi, gdzie dzierżawi karczmę ${ }^{22}$. Zachowując tradycję żydowską, dostosowuje jednak swoją działalność do otaczającej go społeczności i przyswaja niektóre zwyczaje. Życie na wsi wyznaczone jest bowiem nie tylko przez rytm pór roku, ale również przez święta katolickie, które prowadzącemu

18 Tamże.

19 Icchok Lejb Perec, Zamęście, [w:] tenże, Wybór opowiadań, tłum. Anna Dresnerowa, Wrocław 1958, s. 29.

20 Tamże, s. 35.

21 Perec, Wybór opowiadań...

${ }^{22}$ Figura żydowskiego karczmarza należy także do najbardziej charakterystycznych dla literatury polskiej. 
karczmę określają wskazówki działania: „nie można opuścić karczmy w te dni"23.

Konwencja zakończonego tragicznym finałem romansu międzyetnicznego ${ }^{24}$ rozpoczyna się od fascynacji odmienną kulturą ludową. Młodsza córka karczmarza zdradza bowiem „złe skłonności”, które polegają na tym, iż „nie można jej wyciągnąć z karczmy, zwłaszcza w nocy, gdy grają i tańczą" 25 . Jej oczarowanie folklorem, chłopskimi zabawami opisane zostało następująco:

Siedziałaby tam [w karczmie - A. M.] całymi nocami i nie spuszczała oczu z wiejskich dziewuch, z którymi chłopaki żartują, tańczą w wirujących kręgach, śpiewają swoje pieśni, że aż cała karczma drży i dudni ${ }^{26}$.

Pragnący wychować córki wedle żydowskiej tradycji rodzice uciekają się nawet do przemocy, która jednak nie daje pożądanych efektów. Fascynacja chłopską egzotyką, odmiennością, okazuje się silniejsza, wpływa na zachowanie żydowskiej dziewczyny: „Ledwie siostra zaśnie, zeskakuje z łóżka i czy to zima, czy lato stoi boso na podłodze i przez dziurkę od klucza czy szparę w drzwiach lub przepierzeniu przygląda się temu, co się w karczmie dzieje"27. Gdy bohaterka zostaje przyłapana przez matkę i siłą odsunięta od podziwiania żywego spektaklu, „wówczas ciało jej pali jak płomień, a oczy miotają błyskawice, aż matkę strach ogarnia"28.

Zgodnie ze strukturą romansu młoda Żydówka wpada w oko synowi dziedzica, który - wykonując prawdziwie kolonialny gest - proponuje arendarzowi osobliwą transakcję: niejako „zakupu” jego córki. Interesujące jest to, iż używa przy tym argumentu zaskakującego jak na wychowanego w Paryżu jedynaka możnych państwa:

Niech ci się zdaje, że ona jest Esterą, ty Mordechajem, a ja znanym królem Achaszwejroszem... No co? Nie myśl, że ci koronę na głowę włożę! Ale karczmę otrzymasz za darmo na wieczne użytkowanie dla siebie, twych dzieci i wnuków! ${ }^{29}$

${ }^{23}$ Perec, Wybór opowiadań..., s. 191.

${ }^{24} \mathrm{Na}$ temat polsko-żydowskiego romansu międzyetnicznego jako zjawiska znanego w literaturze polskiej XIX w. zobacz m.in.: Inglot, Postać Żyda w literaturze polskiej...; w ujęciu komparatystycznym temat podejmuje: Chone Shmeruk, Legenda o Esterce w literaturze jidysz i polskiej, thum. Monika Adamczyk-Garbowska, Warszawa 2000.

${ }_{25}$ Perec, Wybór opowiadań..., s. 191-192.

26 Tamże, s. 192.

27 Tamże.

${ }^{28}$ Tamże.

29 Tamże, s. 194. 
Czyżby przypisanie młodemu dziedzicowi znajomości Księgi Estery, ważnej dla wyznawców judaizmu, było jakimś śladem pozostawionym przez pisarza, sugerującym zainteresowanie tradycją żydowską czy choćby jej powierzchowną znajomość wśród warstw wykształconych, stykających się we wschodnioeuropejskiej przestrzeni ze środowiskiem diaspory żydowskiej? Los dziewczyny został przesądzony, gdy idąc za radą rabina, ojciec wydał ją za mąż. Zmiana zaś stanu cywilnego oznaczała także przeprowadzkę do miasta. Bohaterka pozostała bardzo piękną, ale całkowicie milczącą, na nic niezwracającą uwagi małżonką. Postrzegana przez otoczenie jako cicha, zachwycająca urodą, wedle słów narratora była „z zewnątrz jak kunsztownie rżnięty kryształ górski” ${ }^{30}$. Jednak bladość twarzy oraz spuszczone oczy jedynie maskowały wewnętrzny dramat dziewczyny: „Wewnątrz czaiła się karczma z jej śpiewem, tańcem, grą" ${ }^{11}$. Poczuciu wyobcowania z codzienności towarzyszyły jej z jednej strony marzenia o młodym dziedzicu, z drugiej zaś - na co warto zwrócić uwagę - fantazje ściśle łączące się z folklorem chłopskim: „starczyło tylko zamknąć powieki, by rozigrała się w niej siła wyobraźni i by ujrzała siebie tańczącą z paniczem w karczmie, pośrodku ogromnego koła żniwiarzy"32. Elementy kultury chłopskiej pojawiały się nawet $\mathrm{w}$ trakcie jej zbliżeń seksualnych z mężem, który tak interpretował zachowanie żony: „Na wiejską modłę pieszczotliwe imiona mi nadaje. Niechaj więc nie otwiera oczu, skoro się tak wstydzi!"33.

Zemstą młodego dziedzica było nie tylko pozbawienie wiejskiego Żyda prawa do arendy, ale nawet niewpuszczenie go na teren wsi. Pilnującym wartownikiem, który miał strzelać, gdyby karczmarz przekroczył granice wioski, okazał się „znajomy wieśniak”, żałujący losu żydowskiej rodziny. O przyjaznych relacjach między nimi świadczy w narracji dookreślenie: „Mówiąc z arendarzem miał łzy w oczach, ale cóż? Jeśli pan rozkazał, z pewnością wykona rozkaz!"34. Warto odnotować, że starając się o nowe miejsce pracy, arendarz znajduje je ponownie na wsi, tym razem bardziej oddalonej od miasta. Osiedla się tam i za zgodą miejscowego dziedzica zakłada sklepik. Jednak procesy, które prowadził, chcąc, by wyrządzone mu krzywdy nie pozostały bez kary, sprawiły, że stał się biedakiem. Po śmierci jego i żony ich druga córka doświadczyła we wsi jedynie przemocy. Traktowanie samotnej żydowskiej kobiety przez miejscowych było

$\begin{array}{ll}30 & \text { Tamże, s. } 195 . \\ 31 & \text { Tamże, s. } 199 . \\ 32 & \text { Tamże. } \\ 33 & \text { Tamże, s. } 200 . \\ 34 & \text { Tamże, s. } 201 .\end{array}$ 
wyjątkowo pogardliwe: „Młodzi chłopcy ze wsi nie dawali dziewczynie spokoju. Ciągłe żarty i ustawiczne wyrzekanie na nędzarkę Żydówkę, która nie pozwala się nawet dotknąć"35. Okazuje się, że bezpieczne bytowanie w środowisku chłopskim możliwe było jedynie wówczas, gdy żydowska kobieta nie przebywała w tym otoczeniu sama. Los starszej córki stał się w jakiejś mierze podobny do życia młodszej, będącej nieszczęśliwą mężatką. Starsza zamieszkała w pałacu i została kochanką panicza, który znalazł ją, gdy w drodze do siostry nocowała w lesie. Narrator wskazuje na analogie siostrzanych losów i kończy opowieść, podsumowując tragiczną dolę obu żydowskich dziewcząt:

Obie chodziły ze spuszczonymi powiekami, obce i zadumane. Ale podczas gdy młodsza siostra grzeszyła duszą przebywającą w czystym ciele, starsza - na odwrót, całkowicie zapominając o ciele, utrzymywała w czystości duszę ${ }^{36}$.

Okazuje się, iż zarówno wejście w przestrzeń kultury chłopskiej, fascynacja odmiennym światem, jak i kontakty ze sferą wyższą (los kochanki panicza) są w przypadku obu kobiet obarczone ryzykiem utraty prawdziwie żydowskiej egzystencji.

\section{„Żydowski dziedzic”}

Bardzo interesującą postacią wiejskiego Żyda utrzymującego wyjątkowe stosunki ze środowiskiem chłopskim jest stary Łajew opisany w powieści $Z$ jarmarku ${ }^{37}$. Uosabia on tych żydowskich mieszkańców przestrzeni wiejskich, którzy z jednej strony stosują strategię adaptacji wybranych elementów kultury dominującej, ale z drugiej strony dokonują także przeobrażeń dzięki działaniom odmiennym od ówcześnie powszechnych wśród chłopów. Czytelnik poznaje go wówczas, gdy Łajew - poddawszy najpierw potencjalnego nauczyciela odpowiedniemu egzaminowi - zabiera go ze sobą na wieś. Już sam przyjazd do majątku Łajewa sprawia, iż otrzymujemy portret „żydowskiego dziedzica”: jego „ogromny pański dwór” kontrastuje z „małymi, niskimi, ciemnymi chatkami chłopskimi” ${ }^{38}$. Gdy tylko woźnica zatrzymał konie przed bramą, „wrota otworzyły się jakby automatycznie. Przy bramie stał chłop z obnażoną głową. Nisko kłaniając się przepuścił

\footnotetext{
35 Tamże, s. 202.

36 Tamże, s. 204.

${ }^{37}$ Szolem Alejchem, Z jarmarku, tłum. Michał Friedman, Wrocław 1989.

38 Tamże, s. 323.
} 
powóz"39. Ów uniżony odźwierny w opowieści usytuowany zostaje - wedle wzorców struktur warstwy dominującej - jako postać bezimienna, jedna z wielu spełniających zadania wyłącznie służebne.

W zasobnym domu Łajewa - zgodnie ze statusem majątkowym gospodarza - funkcję podającego do stołu pełni nieżydowski służący: „Co prawda lokaj jest zwykłym szajgecem imieniem Wańka, ale stary ubrał go i wytresował na pański sposób"40 . O tym, iż Łajew jest postacią bardzo nietypową w środowisku żydowskim, świadczy nie tylko jego zasobna w rozmaite książki - także świeckie - biblioteka czy zamożność, ale również dostosowanie do „pańskiego sposobu” życia. Narrator podkreśla, iż Łajew to: „Oryginał pod każdym względem. Żyd, ale niepodobny do Żyda"41. Swoistość tej postaci wynika m.in. z tego, że bohater - wywodzący się z pobożnej rodziny żydowskiej zamieszkałej w mieście Bogusławiu - nie tylko postanowił zostać gospodarzem na wsi, lecz także zasadniczo różnił się od innych posiadaczy ziemskich. Retoryczne pytania dotyczące motywacji wyboru życia na wsi czy wyliczanie aktywnego współuczestniczenia w rozmaitych pracach rolniczych („Był przy orce, siewie, pieleniu, wykopkach, żniwach. Przy sprzęcie zboża, przy koniach, wołach, krowach”42) kończy konkluzja: „gdyby kiedyś zaszła potrzeba pokazania innym narodom wzoru i przykładu Żyda-dziedzica, właściciela dóbr ziemskich i prawdziwego rolnika, to najlepszy byłby stary Łajew" "43. Ów żydowski ziemianin wprawdzie zgodnie $\mathrm{z}$ niepisanym kodeksem ubiera się jak polscy dziedzice, zatrudnia nieżydowską służbę, przyuczając miejscowych do pracy odmiennej od wiejskiej codzienności - co świadczy o strategiach adaptacji elementów kultury dominującej - ale zasadniczo się od polskich ziemian różni. Nie tylko uczestniczy w różnorodnych pracach w swoim zasobnym gospodarstwie, ale przede wszystkim - co zostało w narracji mocno podkreślone - ma fundamentalnie inny stosunek do chłopów:

Wszyscy bez wyjątku chłopi ze wsi przepadali za nim. Nie bali się go, ale i mieli dla niego szacunek. Oni go po prostu lubili. Lubili go za to, że traktował ich jak ludzi, że obchodził się z nimi jak przyjaciel, jak ojciec. Od poprzednich polskich dziedziców chłopi nigdy czegoś takiego nie zaznali. Godzi się nadmienić, że starsze pokolenie mużyków nie zapomniało jeszcze smaku pańszczyzny. Wielu chłopów

\footnotetext{
39 Tamże.

40 Tamże, s. 323-324.

41 Tamże, s. 325.

${ }^{42}$ Tamże, s. 326.

43 Tamże.
} 
nosiło na swoich plecach ślady chłosty. A tu tymczasem obchodzą się z nimi jak z ludźmi, a nie jak z bydłem ${ }^{44}$.

Ten idealistyczny portret relacji żydowsko-chłopskich pozwala narratorowi wskazać żydowską odmienność - od innych posiadaczy ziemskich Łajewa odróżnia selektywne traktowanie szlacheckiego modelu stosunków społecznych. Wprawdzie „ubrał i wytresował na pański sposób” wiejskiego młodzieńca, czyniąc zeń lokaja, ale własne związki z chłopskim otoczeniem ukształtował na radykalnie odmiennych zasadach.

Dekonstruując rozpowszechniony antysemicki stereotyp, autor wyposaża postać Łajewa w jeszcze jedną cechę: „Poza tym [chłopi - A. M.] żywili do gospodarza ogromne zaufanie. Rzadko kto we wsi był w stanie zliczyć do dwóch. W rachunkach całkowicie polegali na Łajewie. Byli pewni, że ich nie oszuka" ${ }^{35}$. Opisowi tak wyjątkowej relacji między chłopami a żydowskim dziedzicem towarzyszy dodatkowy komentarz odautorski, wyrażony w probabilistycznym rozważaniu, które służy objaśnieniu szerszego zjawiska:

Trudno sobie wyobrazić, jak potoczyłaby się historia narodu żydowskiego i jaką rolę odegralibyśmy w życiu społecznym i ekonomicznym kraju, gdyby nie te niektóre osławione wremiennyje prawiła wprowadzone przez ministra Ignatiewa ${ }^{46}$.

Wskazanie na dominację obowiązującego prawa jako jedną z najważniejszych zasad kształtujących zarówno szanse osiedlania się na wsi, jak i relacje żydowsko-chłopskie sprawia, iż odbiorca może dostrzec też różnorodne komplikacje i uwikłania, które uwydatniały się w środowisku wiejskim.

\section{Wieś - przestrzeń kontaktów żydowsko-chłopskich}

Innym jeszcze zapisem literackim, na który chcę zwrócić uwagę, jest powieść Jehoszuy Perlego Żydzi dnia powszedniego ${ }^{47}$. Autor sytuuje wprawdzie najważniejsze wydarzenia fabuły w klasycznym sztetlu, ale dzięki kreacji jednego z głównych bohaterów, ojca rodziny, jako tego, który często bywa na wsi, gdyż zajmuje się handlem sianem, w niektórych partiach tekstu mamy wgląd w relacje żydowsko-chłopskie. Niewielkie części akcji całego utworu, co warto podkreślić, rozgrywają się bezpośrednio na wsi.

44 Tamże.

45 Tamże.

46 Tamże. Nikołaj Pawłowicz Ignatjew, minister spraw wewnętrznych Rosji w latach 1881-1882.

47 Jehoszua Perle, Żydzi dnia powszedniego, thum. Michał Friedman, Wrocław 1998. 
Jedną z przytaczanych przez narratora historii są dzieje nabycia niewielkiego majątku wiejskiego przez mieszkańca miasteczka, co ze względu na zasobność finansową tegoż bohatera budziło powszechne zdumienie: „Toteż nic dziwnego, że w zwykłe dni pracy wielu Żydów pobiegło do pobliskiego majątku, by na własne oczy zobaczyć, czy Weisówka naprawdę istnieje"48. Okazało się jednak, iż nowy gospodarz istotnie zamieszkał w pobliskiej osadzie wiejskiej: „Cała Weisówka wraz z lasem, łąkami, krowami i kurami należała teraz do Mordechaja-Mendla" ${ }^{49}$.

Spokrewniona z nabywcą posiadłości rodzina narratora zostaje (za pośrednictwem wysłanego ze wsi chłopa) zaproszona przez nowego właściciela w odwiedziny. W drodze na wieś w sobotę spotykają jadące furmanki chłopskie:

Chłopi patrzą na nas odświętnie wypoczętych i wykąpanych. Niektórzy chłopi znają ojca. Łapią się za daszki i pozdrawiają:

- Niech będzie pochwalony...

- Na wieki wieków! ${ }^{50}$

Osobliwością jest tu nie tyle znajomość z mieszkańcami wsi - wszak od nich ojciec narratora kupował siano na handel - ile formuła wymienianych pozdrowień. Brzmi ona bardzo tradycyjnie i wydaje się, że ustalony schemat chrześcijańskiego pozdrowienia zyskuje w tej wersji wymiar wręcz międzywyznaniowy. Okazuje się jednak ograniczony do konwencji pozdrowień, gdyż inne przejawy religijności oglądającemu je po raz pierwszy chłopcu wydają się dość egzotyczne i obce:

Chłopka z dwoma pustymi koszami klęczy przed figurką Matki Boskiej, która wisi na topoli. Figurka jest czarna, bez twarzy. I oto wyłania się szary wilgotny płot rosyjskiego cmentarza. Jest tu chłodno i obco. Krzyże straszą ${ }^{51}$.

Fascynującą przestrzenią w oczach opowiadającego staje się jednak zarówno sad, jak i park pełen kwiatów (nowi właściciele zatrudniają tego samego ogrodnika, który pracował u dawnych dziedziców) oraz obszerny dworek. Jedynie ojciec widywał podobne domy - „często bywał z racji profesji we dworach dziedziców" 52 . Opowieści o dziejach powolnego upadku majątku oraz jego sprzedaży przez owdowiałą dziedziczkę wysłuchują

\footnotetext{
48 Tamże, s. 143.

49 Tamże.

50 Tamże, s. 145.

51 Tamże.

52 Tamże, s. 150-151.
} 
od Mordechaja, a także od starego, miejscowego chłopa. Strategiczny koncept nowego właściciela polegający nie tyle na rozwijaniu zaniedbanego gospodarstwa, ile na budowie cegielni i wykorzystaniu miejscowej gliny do produkcji garnków ostatecznie nie zakończył się długotrwałym sukcesem. Miejscowi takie przemiany wprowadzone w przestrzeń wiejską przyjęli bez entuzjazmu, mimo iż przy produkcji pracowali garncarze goje: „Chłopi, którzy przybywali do miasta, opowiadali, że dym z pieca z wysokim kominem, który służył do wypalania garnków, osiada na koronach topoli. Bociany są w popłochu. Szukają innych miejsc na gniazda" ${ }^{53}$. Wprawdzie przez jakiś czas popyt na wyroby gliniane istniał, ale Mordechajowi nie udało się rozwinąć handlu garnkami na większą skalę. Splajtował i sprzedał wiejski majątek.

Inne kontakty głównego bohatera ze światem chłopskim były raczej okazjonalne - od erotycznych młodzieńczych wtajemniczeń w ramionach służącej Józi, poprzez współpracę ojca ze starym Mateuszem, „furmanem, z którym ojciec jeździł po wsiach, żeby skupować siano u dziedziców"54. Wiedzę o tym świecie czerpał bohater z rodzinnych opowieści, informacje o wsi uzyskiwał dzięki obserwacjom i doświadczeniom ojca: „W Nowym Młynie, w tamtej wsi, z której mój ojciec przybył do miasta, rozciągały się duże rozgrzane pola, otoczone niebieskimi, zaciemnionymi lasami" "55. Dalszy ciąg opisu skonstruowany został prostym językiem, stylizowanym na relację dziecka przekazującego wiedzę o świecie chłopskim zasłyszaną w rozmowach dorosłych:

Chatki w Nowym Młynie były drewniane, prymitywne, złożone z nieheblowanych desek. Dachy kryła słoma, a podłogi ulepione były z gliny. Pożywienie chłopów to zazwyczaj zsiadłe mleko przechowywane w glinianych garnkach. Płaskie bochenki chleba, wypieczone we własnych piecach, uzupełniały posiłek. Latem wieśniacy kąpali się w rzece, sypiali pod stogiem siana i wpatrywali w polną dal ${ }^{56}$.

Nabyta wiedza, dotycząca zarówno praktycznego życia chłopskiego, jak i wiejskiej mentalności czy obyczajów, uzupełniana bywa obserwacja kontaktów ojca z chłopami, którzy jednak tylko na chwilę przychodzili do domu „pana kupca” i nie byli w bliskich stosunkach z całą rodziną.

Do rzeczywistej konfrontacji dochodzi wówczas, gdy ojciec postanawia, że wszyscy wyjadą na wieś, gdzie razem ze wspólnikiem wydzierżawił

\footnotetext{
53 Tamże, s. 160.

54 Tamże, s. 28-29.

55 Tamże, s. 29.

56 Tamże.
} 
łąki, licząc na większy zarobek. Początkowo pomysł ten budzi sprzeciw żony oraz zdumienie dzieci: „Nie rozumiemy tego z dwóch powodów: ojciec nigdy nie prowadził wielkich interesów i nigdy nie wyjeżdżaliśmy na wieś" ${ }^{57}$. Matka wprost formułuje własne obawy: „Daruję ci świeże powietrze, jeśli koniecznie chcesz wiedzieć. Wystarczy, że będziemy wśród samych chłopów"58. Już podróż do nieodległej wsi okazała się ważnym doświadczeniem pozwalającym narratorowi odnotować chłopską odmienność. Oto w trakcie posiłku podczas przerwy w podróży dostrzega bose chłopki robiące pranie w rzeczce; patrzy, jak ojciec „małymi łyczkami pije wódkę”, chłop zaś, który dostał pełną szklankę, ,jednym haustem wypija ją odrzuciwszy głowę do tyłu" ${ }^{\text {. }}$. Na inność chłopską wskazują także tradycyjne, religijne gesty: „Nasz chłop kilka razy zdejmował czapkę przed stojącymi na drodze kapliczkami z Matką Boską" ${ }^{60}$. Wprawdzie rodzina pierwszą noc musi spać na sianie, co jest też nowym doświadczeniem, ale już następnego dnia chłop - zgodnie z obietnicą - wynajmuje przybyszom pokój: „Wyniósł swoje bety, garnki i miski. Zostawił tylko łóżka, stół, krzesła i święte obrazy na ścianach" ${ }^{1}$. Obecność symboli innej religii była postrzegana jako „coś przeciwnego naturze” - zarówno paląca się przed obrazem Maryi lampka oliwna, jak i wiszący nad drugim łóżkiem krzyż nie tylko tworzą egzotyczne otoczenie, lecz także wywołują konkretny niepokój: „Ten krzyż śnił mi się wiele razy. Zdawało mi się, że schodzi ze ściany i kładzie mi się na sercu. Uciska mnie"62. Między rodzicami toczy się nawet dyskusja, czy skłonić chłopa, by zdjął obrazy i krzyż; ojciec jest gotów poprosić o to chłopa, ale mocno wystraszona matka powstrzymuje męża. Osobliwością pobytu na wsi stają się praktyki religijne: „z powodu Najświętszej Panny i krzyża ojciec zmuszony był nakładać tałes i tefilin na dworze" ${ }^{63}$. Takie gesty, raczej mało znane w przestrzeni wiejskiej, budziły zaciekawienie chłopskich dzieci. Narrator na osobności objaśnia im, od kiedy on sam będzie nosił tałes; zapytany - podkreśla, że „wszyscy Żydzi się modlą" ${ }^{64}$.

\footnotetext{
57 Tamże, s. 249.

58 Tamże, s. 250.

59 Tamże, s. 254.

60 Tamże, s. 257.

61 Tamże, s. 259.

62 Tamże, s. 260.

63 Tamże.

64 Tamże.
} 
Śmiech chłopców tłumaczy sobie narrator ich niewiedzą: „,biedni młodzi szajgecy, którzy nie mają pojęcia o tym, czym jest tałes" ${ }^{65}$. Relacje między żydowską rodziną a chłopami układają się jednak dobrze; miejscowi podziwiają matkę narratora czytającą książki, od razu uznając ją za kogoś mądrzejszego. Chłopki korzystają z zasobu jej wiadomości medycznych („Wiedzą, że jej mąż był starszym felczerem”66). Wyraźnie podkreślona zostaje pracowitość wszystkich mieszkańców wsi, ciężko harujących na polach. Sam narrator towarzyszy ojcu w koszeniu łąk, gdzie uczestniczy w obyczaju jedzenia posiłków w trakcie przerw w pracach polowych. Odnotowuje: ,nigdy jeszcze jedzenie tak mi nie smakowało jak właśnie w polu,

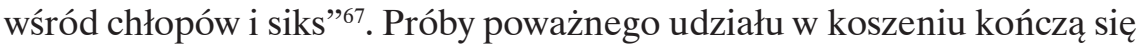
niestety skaleczeniem („Kosa jest za duża dla mnie” ${ }^{68}$ ) oraz awanturą między rodzicami, gdyż matka oskarża ojca o nieszczęście. Nawiązanie przyjaznych stosunków z chłopskimi dziećmi, wspólne zabawy na sianie czy radość z jazdy konnej przytłumione zostają jednak poczuciem alienacji: „Kiedy nadeszła sobota, ogarniał nas smutek i tęsknota kładła się cieniem na sercu" ${ }^{69}$. Wspólnota pracy nie staje się fundamentem wspólnoty kulturowej, doświadczanie radości świętowania jest radykalnie odmienne w przestrzeni wiejskiej, o czym świadczy także fakt, iż piątkową kolację rodzina żydowska spożywa poza domem: „Czyści, wymyci, uwolnieni od powszedniości i chłopskości sześciu dni pracy, wyszliśmy na łąkę, żeby odprawić szabas"70. Jeżeli, co oczywiste, w formule obchodzenia świąt religijnych wyraźnie widać różnice między społecznością polską a rodziną żydowską, to jednak pewne podobieństwo można dostrzec w tym, jak przybysze i chłopi reagują na nadejście letniej burzy. Polscy wieśniacy wystawiają w oknach chat krzyże, a uciekający przed deszczem i piorunami żydowski chłopiec odmawia błogosławieństwa. W obu przypadkach lęk przed żywiołem skłania bohaterów do odwołania się do sfery sacrum. Akceptację i życzliwość mieszkańców wsi widzimy również w chwili, gdy rodzina udaje się „,chłopskim, drabiniastym wozem” do miasteczka na ślub córki: „Chłopi wyszli z chałup i stojąc w progu pozdrawiali nas. Zdejmowali czapki i składali życzenia. Moi koledzy, Janek i Piotrek, wskoczyli na

\footnotetext{
65 Tamże.

66 Tamże, s. 260-261.

67 Tamże, s. 262.

68 Tamże, s. 263.

69 Tamże.

70 Tamże, s. 264.
} 
wóz i przejechali z nami kawałek drogi"’11. Rozstanie z wiejskim światem wyznaczał wyjazd, gdy żydowska rodzina po zbiorze siana opuściła miejsce tymczasowego zamieszkania. Ów dość szczegółowo przywołany tu obraz wsi jest zapisem poprawnych relacji żydowsko-chłopskich, pozbawionych znamion niechęci czy nienawiści, ale też niepozwalających na inną bliskość niż wspólnota pracy czy zabawy. Chłopi w tej perspektywie pozostają na ogół anonimowi (podobnie zresztą jak Żydzi zapisani w opowieści chłopskiej), imiona wyróżniają jedynie tych, z którymi - najczęściej chwilowo zostaje nawiązany sąsiedzki kontakt.

Innymi jeszcze postaciami funkcjonującymi na łamach prozy żydowskiej w wiejskich środowiskach są skupujący produkty rolne żydowscy handlarze czy wędrowni szewcy lub krawcy. Znają oni chłopskie zwyczaje, posługują się lokalnymi odmianami języka i choć przestrzenie wsi nie są dla nich najbardziej naturalnym środowiskiem, udaje im się utrzymać kontakty z chłopami. Oczywiście w świecie przedstawianym przez pisarzy języka jidysz pojawiają się także narracje dotyczące chłopskiej niechęci czy przemocy antyżydowskiej, którym towarzyszy ambiwalencja postrzegania Żydów przez mieszkańców wsi, posługujących się często antysemickim stereotypem (m.in. świadczącej jakoby o żydowskim lenistwie nieumiejętności pracy na roli czy ich wyjątkowej chciwości).

Przyjrzenie się wybranym tekstom prozy jidyszowej jest raczej zakreśleniem wstępnych rozpoznań i początkiem szerszej refleksji. Wskazanie postaci żydowskich bohaterów funkcjonujących w rozmaitych wariantach (arendarz, dzierżawca, „żydowski dziedzic”) wśród wiejskich przestrzeni, w obrębie kultury chłopskiej, to jedynie wstępne omówienie kilku zapisów literackich podejmujących tematykę relacji żydowsko-chłopskich.

Osobna - wartą dodatkowej analizy - sferą kontaktów żydowsko-chłopskich są odbywające się na wsi święta czy inne uroczystości, w których opisach poszukiwać można, jak sądzę, wyznaczanej wedle koncepcji Homiego Bhabhy „trzeciej przestrzeni” ${ }^{2}$ dającej możliwość artykulacji różnych podmiotów, w tym też szansę mówienia i o sobie, tj. Żydach, i o Innych, tj. chłopach ${ }^{73}$.

${ }^{71}$ Tamże, s. 283.

72 Koncepcję badacza oraz wspomnianą kategorię „trzeciej przestrzeni” przywołuję za: Eugenia Prokop-Janiec, Etnopoetyka, [w:] Kulturowa teoria literatury 2. Poetyki, problematyki, interpretacje, red. Teresa Walas, Ryszard Nycz, Kraków 2012, s. 189.

${ }^{73}$ Osobna sfera badań to analiza istniejących tłumaczeń: rozważania dotyczące translacji tekstów literackich oraz obecności w nich rozmaitych wariantów języka lub wtrąceń z języków innych niż podstawowy język tekstu. Jest to jednak materiał na całkiem inny artykuł. 
Jeszcze innym obszarem wzajemnych stosunków żydowsko-chłopskich bywała sfera polityki, czego przykładem może być powieść $W$ lasach polskich $^{74}$ Josefa Opatoszu poświęcona polskiej sprawie 1863 roku. Problem udziału chłopów w przygotowywanym powstaniu powraca w tej perspektywie kilkakrotnie, wielu polskich bohaterów skłonnych jest bowiem uznać, iż ta warstwa społeczna pozostaje bierna, gdyż powstanie traktują jako próbę przywrócenia dawnego ładu społecznego w jego feudalnej postaci. Żydowski bohater nie tylko obserwuje z bliska chłopską nędzę, ale także formy zdecydowanego i gwałtownego buntu skierowanego przeciwko szlachcie.

Radykalną zmianę funkcjonowania przestrzeni wsi oraz środowiska chłopskiego otrzymujemy w narracjach żydowskich autorów poświęconych epoce Zagłady. Bardzo różnorodnym opisom wiejskich przestrzeni oraz chłopskich postaci towarzyszy zasadnicza ambiwalencja. Wieś i społeczność chłopska są postrzegane $\mathrm{z}$ jednej strony jako przestrzeń potencjalnego ocalenia, z drugiej zaś jako obszar zagrożenia ${ }^{75}$.

\section{Bibliografia}

\section{1. Źródła opublikowane}

Alejchem Szolem, Notatki komiwojażera, tłum. Jakub Appenszlak, Warszawa 1958. Alejchem Szolem, Z jarmarku, tłum. Michał Friedman, Wrocław 1989.

Perec Icchok Lejb, Wybór opowiadań, tłum. Anna Dresnerowa, Wrocław 1958.

Perle Jehoszua, Żydzi dnia powszedniego, tłum. Michał Friedman, Wrocław 1998.

\section{Opracowania}

Bałaban Majer, Kiedy i skąd przybyli Żydzi do Polski, Warszawa 1931.

Bartal Israel, Non-Jews and Gentile Society in East European Hebrew and Yiddish Literature, 1856-1914, „Polin” 4 (1989).

Bartal Israel, „Porec” $i$ arendarz. Portret Polaków $w$ literaturze żydowskiej, tłum.

Emilia Padoł, [w:] Polskie tematy i konteksty literatury żydowskiej, red. Eugenia Prokop-Janiec, Marek Tuszewicki, Kraków 2014.

Hein-Kircher Heidi, Blank Inge, I. L. Peretz’ Blick auf das shtetl: Die Reportage über seine Provinzreise in historischer Perspektive, „Aschkenas” 11 (2001), nr 2. Inglot Mieczysław, Postać Żyda w literaturze polskiej lat 1822-1864, Wrocław 1999.

${ }^{74}$ Zob. Alina Molisak, 1863 rok w żydowskiej perspektywie, [w:] Rok 1863. Narodziny nowej Polski, red. Monika Rudaś-Grodzka i in., Warszawa 2016, s. 127-141.

75 Warto przypomnieć, iż wśród wielu publikacji i badań podjętych przez Centrum Badań nad Zagładą Żydów mieszczącym się przy Instytucie Filozofii i Socjologii PAN w Warszawie problematyka wsi i postaw chłopów jest jednym z ważniejszych nurtów refleksji. Badania Centrum dotyczą również literackich zapisów tych zagadnień. 
Kwestia żydowska w XIX wieku. Spory o tożsamość Polaków, red. Grażyna Borkowska, Magdalena Rudkowska, Warszawa 2004.

Miron Dan, The Image of the Shtetl and Other Studies of Modern Jewish Literary Imagination, Syracuse 2001.

Molisak Alina, 1863 rok w żydowskiej perspektywie, [w:] Rok 1863. Narodziny nowej Polski, red. Monika Rudaś-Grodzka i in., Warszawa 2016.

Molisak Alina, Żydzi-chtopi, „Teksty Drugie” (2017), nr 6.

Opalski Magdalena, The Jewish Tavern-Keeper and His Tavern in Nineteenth-Century Polish Literature, Jerusalem 1986.

Petrovsky-Shtern Yohanan, Sztetl. Rozkwit i upadek żydowskich miasteczek na Kresach Wschodnich, tłum. Joanna Gilewicz, Kraków 2014.

Polonsky Antony, Dzieje Żydów w Polsce i Rosji, tłum. Mateusz Wilk, Warszawa 2014.

Prokop-Janiec Eugenia, Etnopoetyka, [w:] Kulturowa teoria literatury 2. Poetyki, problematyki, interpretacje, red. Teresa Walas, Ryszard Nycz, Kraków 2012.

Prokop-Janiec Eugenia, Kategoria pogranicza we współczesnych studiach żydowskich, [w:] taż, Pogranicze polsko-żydowskie. Topografie i teksty, Kraków 2013.

Prokop-Janiec Eugenia, Kulturowe i literackie kontakty polsko-żydowskie, [w:] Polacy - Żydzi. Kontakty kulturowe i literackie, red. Eugenia Prokop-Janiec, Kraków 2014.

Roszkowski Wojciech, Gospodarcza rola większej prywatnej własności ziemskiej w Polsce 1918-1939, Warszawa 1986.

Shmeruk Chone, Legenda o Esterce w literaturze jidysz i polskiej, tłum. Monika Adamczyk-Garbowska, Warszawa 2000.

The Shtetl: Image and Reality, red. Gennady Estraikh, Mikhail Krutikov, Oxford 2000.

The Shtetl: New Evaluations, red. Steven T. Katz, New York 2007.

Studia z dziejów Żydów w Polsce. Materiały edukacyjne dla szkót średnich i wyższych, t. 1, red. Zofia Borzymińska, Warszawa 1995.

Żydzi w Polsce. Dzieje i kultura. Leksykon, red. Jerzy Tomaszewski, Andrzej Żbikowski, Warszawa 2001.

\section{3. Źródła internetowe}

Wirtualny Sztetl, Muzeum Historii Żydów Polskich Polin, http://www.sztetl.org.pl/ pl [dostęp: 4 października 2017].

Alina Molisak

Uniwersytet Warszawski amolisak@uw.edu.pl 